\title{
UNIT OPERATION OF OIL AND GAS FIELDS
}

JOHN C. JACOBS*

\section{THE OBJECTIVES OF UNITIZATION}

In less than a century, petroleum has changed from "a peculiar liquid not necessary nor indeed suitable for the common use of man" 1 to a substance indispensable to the military security and economic prosperity of a modern nation. ${ }^{2}$

Adjudication of claims to property rights in this invaluable substance has been greatly complicated by the circumstances of its occurrence. Petroleum is found in underground reservoirs consisting of porous strata filled with some mixture of oil, gas and water, all under pressure. The reservoirs are of limited volume ${ }^{3}$ and may underlie any number or portions of surface leases. Drilling a well into the reservoir creates a low pressure point to which reservoir oil and gas move, the movements refusing, of course, to respect lease boundaries. ${ }^{4}$

In adjusting property rights to oil and gas, the courts at first followed the "rule of capture," giving a property owner title to all oil and gas produced through well bores located on his land, regardless of the underground source. ${ }^{5}$ Each surface owner consequently was impelled to

* L.L.B. Yale Law School ; Member, American Institute of Chemical Engineers, American Institute of Mining and Metallurgical Engineers, Colegio de Ingenieros de Venezuela.

1. Hail v. Reed, 15 B. Mon. 479,490 (Ky. 1854).

2. SEN. REp. No. 9, 80th Cong., 1st Sess. (1947) (Final Report of Special Committee Investigating Petroleum Resources pursuant to S. Res. 36, 79th Cong, extending S. Res. 253, 78th Cong., 1947, entitled "Investigation of Petroleum Resources in Relation to the National Welfare").

3. Also limited is the total amount of the United States petrolcum resources. The magnitude of these resources is questionable. Optimistic views are given in PEW, Unired States Petroleusr Resources (1945) and Rostow, A Natiokral Policz fos tae On INDUSTRY 31 (1948). Less optimistic is that of Baker and Logan, Significanee of World Petroleum Production Trends, 10 Petroleum Techasology, No. 4 (July, 1947).

4. A simplified description of the mechanics of petroleum production is given in Moses, The Constitutional, Legislatize, and Judicial Grouth of Oil and Gas Conseristion Statutes, 13 Misss. L. J. 353, 353-4 (1941); and in Ely, The Conscriation of Oil, 51 HARV. L. REv. 1209, 1219 (1938). More complete and more technical explanations are in Mituler, Function of Naturas Gas in the Production of Oll (1929); Gibson, Scientific Ustit Control, 1 Scrence of Perroleuar 534 (1938). The most recent and complete description is given in Consmittees on Reservorr Devezoparents asid Operatro:i or the Standard Oil Co. (N.J.) and the Huarble Ori and Refning Co., Jonit Progress Report on Reservorr EFfictency and Well Spacing (1943).

5. See Hardwicke, The Rule of Capture and Its Implications as Applied to Oil and Gas, 13 TEx. L. REv. 391 (1935) ; see also Hardwicke's testimony before the Cole Committee, in Hearings before a Subcommittce of the Commiltce on Interstate and Forcion Commerce, on H. Res. 290 and H. Res. 7372 76th Congress, 3rd Sess., (1939) at page 1479; Hardwicke, Oil Conscrzation: Statutes, Administrations, and Court Reciczi, 13 Miss. L. J. 381,384 (1941). 
reduce the underground oil and gas to surface storage at the earliest possible time. As a result, there occurred great waste in production, and the frequent taking, through underground drainage, of more oil and gas than originally underlay the taker's land. ${ }^{6}$

In the light of these circumstances, state and federal governments have enacted statutes designed to prevent waste and to provide for each surface owner a fair share of the underlying reservoir contents. ${ }^{7}$ Under the better present day practice, an administrative agency employs a complex of control techniques, including production control or proration, well-spacing, and gas waste control..$^{8}$ Proration has as its

6. National Resources Committee, Energy Resources and National Policy 186 (1939). See also Oliver and German, Changes Necded in Oil Ozenership Law, 30 Ont and Gas Journal, No. 10, p. 15 (July 23, 1931); Gibson, Scientific Unit Control, 1 TuE Science of Petroleum 534 (1938); Ely, The Conscrvation of Oil, 51 Harv. L. Rev. 1209, 1218 (1938).

7. See 5 Sumarers, OIL AND Gas, \$\$ 921-71 (1939 and Supp. 1947) for the complete statutes. Myers, Spacing, Pooling and Field-Wide Unitiation, 18 Mrss. L. J. 267, 282 (1947) lists statutes providing for well spacing and pooling of leases to form drilling blocks of one-well drainage area. Foster \& Hamill, Summary of The Oil and Gas Conservation Laws of the Tharious States in American Petroleum Institute, Finding and ProducING OrL 283 (1939) contains a summary of state and national statutes pertaining to petroleum production. See also Ely, The Oil and Gas Conservation Statutes (1933) and American Petroleum Institute, Secondary Recovery of Oil in the United States, c. 3 (1942).

The Legal Committee of the Interstate Oil Compact Commission has developed a set of model oil and gas conservation laws. A copy may be obtained by writing the Secretary of the Commission at the State Capitol Building, Oklahoma City, Oklahoma.

8. For the reader's convenience the following technical terms are here defined:

Condensate-A condensate field is one in which the petroleum exists in a gaseous state. If the reservoir pressure is reduced, liquid condenses on the reservoir rock and is unrecoverable. To provent this loss, condensate fields are exploited by a method known as cycling or recycling. This method involves pumping the gas produced from the wells back into the reservoir after liquid fractions have been separated out.

Gas Cap-In some reservoirs there occurs or has occurred a separation of the reservoir fluids. In such a case the gas is in the upper parts of the reservoir, and the oil in the lower parts. Segregated gas of this type is spoken of as a gas cap. The lower oil is spoken of as dozendip oil.

Gas Waste Control-Included are controls preventing use of gas in carbon black manufacture, letting gas escape into the air, and operating wells which produce oil at excessive gas-oil ratios (the cubic feet of gas which flow from the well with each barrel of oil).

Lessee-Virtually all wells today are drilled by companies on leaseholdings from the landowners or their assigns. Therefore, throughout this discussion the owner and cxploiter of subterranean oil rights will be referred to as the lessee.

Pooling-In order to prevent the drilling of unnecessary wells, some states require that the owners of small tracts combine these tracts to provide an area which one well will efficiently drain. The state will then allow the drilling of a single well on the pooled lease. This practice is known as pooling, and is to be distinguished from unitisation. Unitization involves combining leases on a field wide basis, rather than in a single well area.

Proration-Proration is a method of waste prevention through production control 
aim the maximizing of recovery from the field as a whole, but is limited to the recoveries available by primary methods only, and is complicated by the extreme difficulty of determining per-well allowables which will result in no underground drainage between leases. ${ }^{9}$ Tell-spacing is designed to insure equitable taking and to minimize investment in production facilities. It has proven ineffective in that, as a matter of practice, large numbers of exceptions to the established pattern have been granted ${ }^{10}$ and because general spacing rules cannot give the exactness of location which may be required from the geological standpoint. ${ }^{11}$

utilized by many states. It involves assigning to each well a fixed daily quantity of production known as the per-well allowable.

Recovery-Recovery refers to the percentage of the oil-in-place in the reservoir which is reduced to surface storage, and may vary from 20-80\%. Recovery is by primary methods whenever the reduction to surface storage is brought about by means of the gas or water naturally in the reservoir. Whenever the natural reservoir forces are augmented by gas or water pumped back from the surface, the procedure is a secondary recovery method. Secondary recovery methods presently in use include repressuring, pressure maintenance, and water flooding.

Well Spacing-To prevent indiscriminate drilling of wells, some states provide that no well shall be drilled unless it is to be the only well within a given area (usually 10 to 40 acres for oil wells).

9. The theory and practice of prorationing are discussed in Marshall and Meyers, Legal Planning of Petroleum Production, 41 Y ALE L. J. 33 (1931); MIarshall and Areyers, Legal Planning of Petroleum Production: Two Ycars of Proration, 42 Yaxe L. J. 702 (1933); Comment, Proration of Petrolcum Production, 51 YALE L. J. 603 (1942). For the recent "most efficient ratio" concept of proration see 6 INTERSTATE OIL Co:mpacr QuasTERLY BuLLETIN (hereinafter referred to as IOC Q. BuLL), No. 2, p. 60 (Aug. 1947).

10. In early statutes which inflexibly provided for well spacing of, say, 10 acres, it was necessary to allow exceptions in order to avoid confiscation of the mincrals below holdings of less than 10 acres. Under the modern statutes which require pooling to form the standard size drilling block, the need for granting such exceptions is obviated.

11. On the general subject, see Walker, The Problem of the Small Trat under Spacing Regulations, 16 TEx. L. Rev. 370 (1938) ; and I Suarsers, OIL Axd GAS, \$\$ \$3-6 (1927 and Supp. 1947).

On the matter of granting exceptions see: Burford v. Sun Oil Co., 319 U.S. 315, 324 (1943); Railroad Commission v. Rowan and Nichols Oil Co., 311 U.S. 570, 575 (1941); Brown v. Humble Oil and Refining Co., 126 TEx. 296, 300, 83 S.W. 2d 935, 937 (1935); Ely, The Conservation of Oil, 51 HARv. L. REv. 1209, 1233 (1938); Note, 24 TEx. L. REv. 97, 98 (1945).

It should be pointed out that, assuming all wells are properly operated as to gas wastage, well spacing has no effect on recovery. Cosnamtres os Resenvom DenelopMIENT ANd Operation, op. cit. supra note 4, at 59; Craze and Buckley, $A$ Factual Analysis of the Effect of Well Spacing on Oil Recovery in 25 Axs. PET. INsT. IV (1945) (paper presented to the Division of Production Group Session on Well Spacing before the Twenty-fifth Annual Meeting and Victory Jubilee of the American Petroleum Institute, Chicago, Ill., Nov. 14, 1945) ; Vietti, and others, The Relation betwecn Well-Sfacing and Recovery in id. at 8 (1945) (presented at the same meeting as the Craze and Buclsey paper).

It should also be noted that, while no complete data are available, a trend toward wider spacing under modern statutes is reported by Stakdard OrL Cospra:Tx (N.J.), 
Gas waste regulation, designed to increase recoveries and protect correlative rights in reservoir energy, is also of limited effectiveness: state-wide gas-oil ratio standards do not provide the individual well control necessary to minimize gas production, nor can operators be required to save gas by returning it to the reservoir. ${ }^{12}$ Consequently, today, in spite of the continual improvement in oil conservation laws and their enforcement, the production of oil involves the wastage of large quantities of gas, the drilling of unnecessary and improperly located wells, and the realization of low recoveries. ${ }^{13}$

Engineers have long since ${ }^{14}$ devised a method of producing oil which corrects all the above defects, making possible maximum recovery at minimum cost together with equitable distribution of the production among the surface owners. This method, known as unit operation, is based on the scientific approach of treating the reservoir, rather than the lease, as the entity for planning production. In unit operation, all surface lessees over a given reservoir agree to treat their properties as a single lease, the project being carried out by a single operator responsible to a committee on which all lessees have representation. ${ }^{15}$ Lease drainage is then disregarded; each lessee receives a proportion of the unit's total production determined by the amount of oil which originally underlay his lease. Unit operation makes possible the increase of recoveries up to the maximum possible with secondary recovery methods; the number of wells drilled may be kept to an

Conservation: Making the Most of OUR OII. (1947). It is here reported that "before 1929 , only seven percent of Texas fields were drilled on a spacing as large as one well to each 20 to 30 acres. Since 1935, more than a quarter of its fields have been drilled on that basis, and 14 percent are on a 40 -acre spacing."

12. See Ohio Oil Company v. Indiana, 177 U.S. 190 (1900) (venting gas to the air); Walls v. Midland Carbon Co., 254 U.S. 300 (1920) (carbon black manufacture) ; Report of Regulatory Practices Committee, 6 IOC Q. Bull., Nos. 3 and 4, p. 97 (Dec. 1947) (gasoil ratio regulation).

While gas return cannot be ordered directly, a recent Texas decision, Railroad Commission v. Shell Oil Co., 206 S.W. 2 d 235 (Tex. 1947) indicates it can perhaps be compelled by indirect means. There, the court upheld the statutory power of the Railroad Commission to shut in a field to prevent gas wastage where it was economical to install equipment for utilizing the gas.

13. Williams, Legal Aspects of Unitization, 6 IOC Q. BuLl., Nos. 3 and 4, p. 58 (Dec. 1947).

14. See chapters on unitization in (1930) and (1931) AMERrCan INSTrTuTE of Mining and Metallurgical Engineers, Petroleun Development and Technology (hereinafter cited as AIMME, PET. DEV. AND TECH.).

15. Other plans involve the use of an operator without a supervising Committe, or a committee without a designated operator.

Typical contracts for unitizing are given in Mrdcontrinent OrL and Gas Associntion, Handbook on Unitization of OIl Pools 81 (1930); Myers, Spacing, Pooling and Field Wide Unitization, 18 Mrss. L. J. 267, 275 (1947); and 12 FED. REG. 528 (1947) giving the recommended form of unit or cooperative agreements to apply to production from federally owned lands. 
economic minimum; each well may be located exactly as geologic considerations dictate; gas conservation through reinjection into the reservoir becomes a possibility; and, through selective production of wells, gas production per barrel of oil may be kept to a minimum. Unit operation is adaptable to oil, gas, or condensate fields, and may be beneficially applied either in the development or production stages of the field's life. ${ }^{16}$

\section{THE NEED FOR COMPULSORY UNIT OPERATION}

In spite of the obvious advantages of unit operation, and the number of years over which it has been espoused by most engineers and many lawyers, there has been little utilization of the technique. ${ }^{17}$ This failure

16. Myers, supra note 15, at 272; Moses, Some Legal and Economic Aspects of Unit Operations of Oil Fields, 21 Tex. L. REv. 748, 756 (19.43) ; Pressler, Legal Problcms Involved in Cycling Gas iin Gas Fields, 24 TEx. L. Rev. 19 (1945) ; Brown and Aryers, Sontc Legal Aspects of Water Flooding, 24 TEx. L. REv. 456 (1946); King, Pooling and Unitization of Oil and Gas Leases, 46 MICH. L. REv. 311 (1948); Oliver and Umpleb;, Principles of Unit Operation, AIMIMIE, PET. DEv. AND Tecir. 105 (1930); Corbett, Suggested Procedure for the Exploitation of an Oil Bcaring Sirneture by Unil Opertion, AIMME, PET. Dev. AND Tech. 128 (1930); Gibson, supra note 4.

17. There are no recent complete data on the extent to which unit operation is practised. The most recent data (1948) indicate 143 unit projects exist. Rescarch and Coordinating Comnititee, Report, 6 IOC Q. BuLn., Nos. 3 and 4, p. 92 (Dec. 1947). Another recent survey, which is admittedly incomplete, shows details of 47 units operating for secondary recovery and pressure maintenance purposes. BenIr, Uiritizatro:i of Ort FIEIDS IN THE UNited States (presented before the Spring Miceting of the Mid-Continent District, API Division of Production, Amarillo, Tesas, 21ay 22-23, 1947).

In 1939 only 185 pools were operated under unit agreements out of 3000 in the United States amenable to the tactic. See testimony of Lindsey before the 1939 Cole Committee in Hearings before Subcommittee of the Committee on Intcrstale and Forcign Commerce on H. Res. 290 and H. Res. 7372, 76th Cong., 3rd Ses5., 475, 501 (1939).

By 1947 only the Federal government and one state, Olilahoma, had passed all-purpose compulsory unitization statutes. See 30 U.S.C.A. \$226e (Supp. 1947) and $520 \mathrm{rrd}$. Stat. ANN. \$286.1-286.17 (Supp. 1947). The federal statute, which applies to the "public domain," has been extended to "federal acquired lands" by Pub. L. No. 382, 80th Cong., 1st Sess. (Aug. 7, 1947). There are no statutes regarding the conditions on which the government's recently acquired "tidelands" will be leased. See United States v. California, 332 U.S. 19 (1947). Experiences in applying the Federal statute are reported at: Testimony before the Cole Committee, supra note 5 at 397; and SE:r. REP. 1392, 79th Cong., 2nd Sess.; Hearings before Stbcommittee of the Public Lands and Surveys Conmittee, on S. 1236, 79th Cong., 1st Sess. 258, 260, 301, 317, 333, 339, 343 (1946) ; id. at 10,17, 19, 33, 45, 154, 169, 181, 194, 201, 207, 222, 223 (1945); Hcarings before Comnittee on Public Lands, on $H$. R. 3711, 79th Cong., 2nd Sess. 6, 16, 60, 83, 84, 87 (1946).

Four states have compulsory unitization statutes covering only condensate ficlds: Alabama, 26 Code of AlA. §179(35) (Supp. 1947); Georgia, GA. Cone Aisi. §43717 (b) (Supp. 1947) ; Louisiana, LA. GEN. STAт. § 4741.14(b) (Dart Supp. 1947) ; Florida, Fla. Stat. Ann. \$377.2S (Supp. 1947). Texas has specific legislation prolibiting the Railroad Commission from ordering compulsory field wide unitization. TEx. Civ. SrAr. Art. 6014 (g) (Vernon 1937). Voluntary unitization of gas fields is, however, permitted. Tex. Crv. Stat. Art. 6008, \$21 (Vernon 1937). 
can be attributed to (1) the highly developed individualism of the American entrepreneur, (2) the numerical multiplicity of the parties holding interests in oil and gas fields, and (3) certain presumed legal and organizational objections to unit operation.

Individualism accounts for the holdouts who refuse to unitize under any conditions. Such persons fail to see that their control over the exploitation of their property is probably greater under the representative committee system of unit operation than it is when exploitation patterns are set by the greediest operator in the field, or, under conservation statutes, by an administrative agency. Such persons also fail to see that unitization is to their financial advantage. Their point of view emphasizes the short term advantages of an operator's being able, in the absence of unitization, to operate at maximum allowables and perhaps drain adjoining leases. It ignores the long term advantages of unitization in guaranteed greater return and the short term advantage of immediately enhancing the value of the individual interests involved. ${ }^{18}$

The physical nature of oil reservoirs dictates that practically 100 per cent of the leases in a field be included in a plan of unit operation for satisfactory results. ${ }^{19}$ The law requires that each party to a lease contract approve any plan of pooling or unitization which intends to change the rights or duties under the contract. ${ }^{20}$ These two considerations, plus the point that the typical oil field involves a multiplicity of interestsespecially royalty interests -indicate the tremendous amount of work required to gain approval of a unit plan. ${ }^{21}$ To obviate the difficulty of contacting the many persons involved and the unfairness of allowing a few parties to block the adoption of a unit agreement, the concept of compulsory unit operation was devised. Here a governmental administrative agency takes jurisdiction for unitization purposes when petitioned by, say, 60 per cent of the lessees in a field, and, if convinced that unitization is in the public interest, can order it, regardless of minority objections. ${ }^{22}$ In view of the meager progress made toward adopting unitization as a production means, and of the seeming invulnerabilty of individualism and multiplicity of interests to voluntary negotiation and education, it is submitted that the only feasible method of instituting unit operation is by means of "compulsory" statutes. ${ }^{23}$

18. 46 OIL and Gas Journat No. 49, p. 64 (April 8, 1948).

19. Cole Committee Hearings, stupra note 5 , at 391 et seq.

20. Knight v. Chicago Corp., 144 Tex. 98, 188 S.W.2d 564 (1945); Brown v. Smith, 141 Tex. 425, 174 S.W.2d 43 (1943).

21. King, supra note 16 , at 327 .

22. The supervising administrative agency must make several detailed findings. See note 80 infra.

23. For approval of this view, see King, supra note 16 , at 339 . NATtoNAL REsources Committee, Energy Resources and National Policy 214 (1939); Marshall and Meyers, supra note 9, 41 YALE L. J. 33, 63 (1931) and 42 YALE L. J. 702, 742 (1933); 
Compulsory unit operation statutes could be enacted by either the several states or the Federal Government. Passage of a federal statute would offer the benefits of single legislative action, nationwide uniformity in conservation standards, and possibly greater consideration of the consumer in setting conservation standards. ${ }^{24}$ Passage of state statutes, on the other hand, would have the advantages of decentralized government, including making use of the expertise and experience which state administrative agencies have developed over past decades; flexibility in conservation standards; and the economic and political advantages of allowing several boards, rather than one, to appraise the future supply and demand picture. ${ }^{25}$ On these grounds, the passage of state statutes seems the better solution to this problem. Politically, it is the only solution presently capable of realization. ${ }^{20}$

\section{OBJECTIONS TO STATE COMPULSORY UNITIZATION STATUTES}

Admitting that unit operation is the most scientific method of exploiting a reservoir, and that some degree of compulsion is necessary to institute a regime of unit operation, it is still sometimes argued that

A.B.A. Consas., Report III of Federal OIL Conservation Bonro 4, 26 (1929); German, Compulsory Unit Operation of Oil Pools, 20 CaLIF. L. Rev, 111 (1932); Williams, supro note 13.

Contrary views are expressed in Moses, supra note 16; Cole Committee Hearings, supra note 5 , at $1440,1785,1963$.

24. See Rostow, op cit. stpra note 3, at 119 et seq.; Natronar. Resources Co:nantTEE, op. cit. supra note 23 , at 231.

25. See Hardwicke, Illig and Patterson, The Constitution and The Contincutal Shelf, 26 TEX. L. REv. 398, 432 (1948).

26. It may be objected that the passage of state unitization statutes, instead of a federal statute, does nothing to correct the price stabilization aspect of proration. See Rostow, op. cit. supra note 3 , at 122 . In considering the price stabilizing aspect of proration it should be remembered that the problem is one of degree, since any lind of conservation control, by whomever instituted and however "pure" its basis in natural scientific fact, necessarily has an effect on price. Second, it does not readily appear why, if proration does result in a kind of price fixing actionable at law, it cannot be corrected by court action, or why a fault in one part of the state conservation program justifies turning the whole program over to federal authorities, especially in view of the continuous progress the states have made in basing their conservation program on objective engineering standards.

Once compulsory unit operation statutes are in force, proration in its present perwell-allowable form, would be unnecessary for the unitized fields. The only production standards necessary would be of an engineering nature regarding gas production, water production, and reservoir pressure decline as related to oil production and reservoir characteristics. Such standards would be applied only to the field as a whole. Consequently the presence of a unitization statute would not be a hindrance to an effort to attack proration as a price fixing device.

It must be admitted that state laws would not effectively cover pools crossing state borders. Few such pools have been discovered to date, however, and it would seem that their administration might better be the subject of interstate compacts than the expense for otherwise undesirable federal legislation. 
state statutes are not feasible because of definite legal and organizational objections. These are principally: (1) compulsory unit operation is an unconstitutional infringement of property rights; (2) unit operation infringes the anti-trust laws; (3) unit operation increases the lessee's liabilities and makes uncertain his rights under the lease; (4) unit operation will increase the tax burden of the participants; and (5) the small property owner will not be treated fairly under unitization.

\section{Constitutionality}

The unconstitutionality argument can be refuted by two lines of precedent: holdings that specific oil and gas conservation measures analogous to unitization are within the police power; and decisions that the common management of adjoining properties may be required under the police power where, because of their peculiar natural condition, the properties cannot be fully enjoyed under management in severalty. ${ }^{27}$

Since 1900, when the Supreme Court laid the foundation in Ohio Oil Co. v. Indiana, ${ }^{28}$ the courts have upheld oil and gas conservation statutes providing for proration, ${ }^{29}$ gas waste prevention, ${ }^{30}$ well-spacing and pooling, ${ }^{31}$ and field-wide unitization in condensate fields. ${ }^{32}$ Here the courts have decided that when the police power is reasonably exercised to the ends of preventing waste, ${ }^{33}$ protecting correlative rights, ${ }^{34}$

27. Accord: Moses, supra note 16, at 760; German, Compulsory Unit Operation of Oil Pools, 20 CalIf. L. Rev. 111 (1932); Merrill, Evolution of Oil and Gas Lazw, 13 Miss. L. J. 281, 290 (1941).

28. 177 U. S. 190 (1900).

29. Railroad Commission v. Rowan and Nichols Oil Co., 310 U.S. 573 (1940), 311 U.S. 570 (1941) ; Champlin Refining Co. v. Corp. Comm. of Okla., 286 U.S. 210 (1932); Corzelius v. Harrell, 143 Tex. 509, 186 S.W.2d 961 (1945). But see Thompson v. Consol. Gas Utilities Corp., 300 U.S. 55 (1937) (proration order not upheld).

30. Ohio Oil Co. v. Indiana, 177 U.S. 190 (1900); Walls v. Midland Carbon Co., 254 U.S. 300 (1920) ; People v. Associated Oil Co., 211 Cal. 93, 294 Pac. 717 (1930); Bandini Petroleum Co. v. Superior Court, 284 U.S. 8 (1931).

31. Well Spacing: Burford v. Sun Oil Co., 319 U.S. 315 (1943) ; Oxford Oil Co. v. Atlantic Oil Producing Co., 22 F.2d 597 (C.C.A. 5th 1927), cert. denicd, 277 U.S. 585 (1928) ; Brown v. Humble Oil and Refining Co., 126 Tex. 296, 83 S.W.2d 935 (1935), But see Bernstein v. Bush, 29 Cal.2d 773, 177 P.2d 913 (1947) (well spacing statute held invalid). Pooling: Hunter Co. Inc. v. McHugh, 320 U.S. 222 (1943); Note, 16 TuL. L. REv. 477 (1942); Marrs v. City of Oxford, 32 F.2d 134 (C.C.A.8th, 1929) cert. denied, 280 U.S. 573 (1929); Patterson v. Stanolind Oil and Gas Co., 305 U.S. 376 (1939); Croxton v. State, 186 Okla. 249, 97 P. $2 d 11$ (1939).

32. Critchton v. Lee, 209 La. 561, 25 So. 2 d 229 (1946).

33. Ohio Oil Co. v. Indiana, 177 U.S. 190 (1900); Champlin Refining Co. v. Corp. Comm. of Okla., 286 U.S. 210 (1932) ; Corzelius v. Harrell, 143 Tex. 509, 186 S.W. 2d 961 (1945) ; People v. Associated Oil Co., 211 Cal. 93, 294 Pac. 717 (1930) ; Hunter Co. Inc. v. McHugh, 320 U.S. 222 (1943); Patterson v. Stanolind Oil and Gas Co., 305 U.S. 376 (1939) ; Thompson v. Consol. Gas Utilities Corp., 300 U.S. 55 (1937).

34. Patterson v. Stanolind Oil and Gas Co., 305 U.S. 376 (1938); Thompson v. Consol. 
or abating nuisances, ${ }^{35}$ there is no denial of equal protection of the laws, ${ }^{36}$ taking of property without due process of law, ${ }^{37}$ impairment of the obligations of contract, ${ }^{38}$ interference with interstate commerce, ${ }^{33}$ or unconstitutional delegation of legislative powers. ${ }^{49}$

The constitutionality of compulsory unit operation for general purposes, that is, for all types of fields and stages of exploitation, is supported most strongly by the favorable decisions on compulsory pooling and on compulsory unitization of condensate fields. Unit operation for general purposes differs from pooling principally in areal extent of the properties involved, ${ }^{41}$ and from unitization of condensate fields only in that the engineering proof of the necessity for unit operation is more easily made in the case of condensate fields than for almost any other type.

Gas Utilities Corp., 300 U.S. 55 (1937) ; Champlin Ref. Co. v. Corp. Comm. of OHa., 286 U.S. 210 (1932) ; Bandini Petroleum Co. v. Superior Court, 284 U.S. 8 (1931); Ohio Oil Co. v. Indiana, 177 U.S. 190 (1900); Oxford Oil Co. v. Atlantic Oil Producing Co., 22 F. 2d 597 (C.C.A. 5th, 1927), cert. denied, 277 U.S. 585 (1928); Walls v. Midland Carbon Co., 254 U.S. 300 (1920) ; Corzelius v. Harrell, 143 Tex. 509, 185 S.IW. 2d 961 (1945); Hunter Co. v. M1cHugh, 320 U.S. 222 (1943).

35. State v. Ohio Oil Co., 150 Ind. 21, 49 N.E. 809 (1898).

36. Champlin Ref. Co. v. Corp. Comm., 286 U.S. 210 (1932) ; Walls v. Mfidland Carbon Co., 254 U.S. 300 (1920); Danciger Oil and Ref. Co. v. R.R. Comm., 49 S.IV. 2d 837 (Tex. Civ. App. 1932) ; Oxford Oil Co., v. Atlantic Oil Producing Co., 22 F2d 597 C.C.A. 5th 1927), cert. denied, 277 U.S. 585 (1928) ; Hunter Co., Inc. Y. MrHugh, 202 La. 97, 11 So.2d 495 (19.4) ; Patterson v. Stanolind Oil and Gas Co., 182 Ol:1. 155, 77 P.2d 83 (1938).

37. Champlin Ref. Co. v. Corp. Comm., 286 U.S. 210 (1932); Ohio Oil Co. v. Indiana, 177 U.S. 190 (1900); Oxford Oil Co. v. Atlantic Oil Producing Co., 22 F2d 597 (C.C.A. 5th 1927), cert. denied, 277 U.S. 585 (1928); Danciger Oil and Ref. Co. v. R.R. Comm., 49 S.W. 2nd 837 (Tex. Civ. App. 1932); People v. Associated Oil Co., 211 Cal. 93, 294 Pac. 717 (1930); Bandini Petroleum Co. v. Superior Court, 284 U.S. 8 (1931); Crichton v. Lee, 209 La. 561, 25 So. 2d 229 (1946); Hunter Co. Inc v. MicHugh, 202 La. 97, 11 So. 2d 495 (1942) ; Patterson v. Stanolind Oil and Gas Co., 182 Okl. 155, 77 P. $2 \mathrm{~d} 83$ (1938).

38. Walls v. Midland Carbon Co., 254 U.S. 300 (1920); Oxford Oil Co. v. Atlantic Oil Producing Co., 22 F.2nd 597 (C.C.A. 5th 1927), cert. denied, 277 U.S. 585 (1923); Crichton v. Lee, 209 La. 561, 25 So. 2d 229 (1946); Patterson v. Stanolind Oil and Gas Co., 182 Okl. 155, 77 P. 2d 83 (1938); Croxton v. State, 186 Olsl. 249, 97 P. $2 d 11$ (1939).

39. Champlin Ref. Co. v. Corp. Comm., 286 U.S. 210 (1932); Danciger Oil and Ref. Co. v. R.R. Comm., 49 S.W. 2d 837 (Tex. Civ. App. 1932).

40. Oxford Oil Co., v. Atlantic Oil Producing Co., 22 F.2d 597 (C.C.A. 5th 1927), cert. den. 277 U.S. 585 (1928) ; People v. Associated Oil Co., 211 Cal. 93, 294 Pac. 717 (1930) ; Danciger Oil and Ref. Co. v. R.R. Comm., 49 S.IV.2d 837, 841 (Tes. Civ. App. 1932) ; Corzelius v. Harrell, 143 Tex. 509, 186 S.W. 2d 961 (19.45); Bandini Petroleum Co. v. Superior Court, 284 U.S. 8 (1931); Hunter Oil Co. v. AfcHugh, 202 La. 97,11 So. $2 d 495$ (1942) ; Patterson v. Stanolind Oil and Gas Co., 182 Okl. 155, 77 P. 2 d 83 (1938).

41. Since pooling involves relatively small areas, participation is upon a uniform acreage basis, rather than on oil-in-place as in unitization. 
It has been suggested that regardless of the validity of other types of oil and gas conservation measures, compulsory unitization should be classified by the courts as an unconstitutional use of the police power because the engineers cannot prove the increased recovery to be realized from unit operation, as compared with other conservation methods, with sufficient accuracy to convince the courts of the reasonableness of the additional interference with property rights. ${ }^{42}$ The courts have recognized the engineers' long asserted ability to estimate accurately the amount of recoverable oil-in-place in reservoirs, after a certain amount of development work has been completed. ${ }^{43}$ In justifying unit operation, estimates of recovery may be made for the instances of operating with and without unitization. These same estimates may be used to determine property interests in the proposed unit. In the absence of the data necessary to accurate estimates, unitization should be required on an acreage participation basis initially, the basis being changed to oil-in-place once sufficient data are available. ${ }^{44}$ In this instance unitization is justified on the possible percentage gain in recovery regardless of the magnitude of the pool in question. Nor should the assumption that unitization represents a greater infringement of property rights go unchallenged. ${ }^{45}$ Admittedly, under unit operation the possibility exists that no wells will be drilled on a given lease, but, as pointed out previously, under unit operation the parties in interest have at least as effective control over the exploitation of their oil and gas as under any other system. ${ }^{46}$ In the final analysis the taking of property rights by unit operation means that the chance to capture more than a fair share of the reservoir contents is gone. ${ }^{47}$ In exchange, the lessee has a guarantee of greater long term returns; all owners of the reservoir are insured a fair share of the production; and the public has the advantage of a less wasteful exploitation of a natural resource.

42. Hardwicke, Testimony before the Cole Committee, supra note 5, at 1494; Hardwicke, Oil Conservation: Statutes, Administration and Court Revicw, 13 Miss. I. J. 381, 308 (1941); Moses, Some Legal and Economic Aspects of Unit Operation of Oil Fields, 21 TEx. L. Rev. 748, 768 (1943).

43. Brown v. Humble Oil and Ref. Co., 126 Tex. 296, 83 S.W. 2d 935, 940 (1935), 126 Tex. 296, 314, 87 S.W.2d 1069 (1935). Testimony before the Cole Committec, supra note 5, at 498; AIMME, PET. Dev. AND TECh. 31 (1931).

44. The amount of oil in place beneath different uniform acres is not the same, but varies with the thickness of the underlying oil-bearing strata.

45. See Oliver and Umpleby, Principles of Utit Operation, AIMME, PET. DEv. AND TECH. 105, 116 (1930).

46. Another type of property taking claimed is deferment of production in the case where a unitized field is completely delineated before any production takes placc. Such deferment would never be necessary to unitization except when a showing could be made that deferred production would maximize the present value of future production. There, the deferment would be to the advantage of the "average" participant.

47. See Marrs v. City of Oxford, 3 F. 2d 134, 140 (C.C.A. 8th 1929), cert. denict, 280 U.S. 573 (1929). 
The second line of cases approving compulsory joint management of properties and sharing of expenses and benefits under state statutes are those involving swampland drainage districts, irrigation districts, and authorized overflowing of an upper riparian's land by a dam builder. ${ }^{48}$ In these cases, the courts readily comprehended the fact that the peculiar natural condition of the properties involved precluded their full enjoyment unless all or nearly all of the owners joined in a common scheme of management. Compulsory unit operation is irresistably analogous.

\section{The Monopoly Problem}

The United States has long favored a policy of competition as opposed to combination among business enterprises. As embodied in the Sherman Act, ${ }^{49}$ the policy prohibits both restraining trade and monopolizing commerce. As interpreted, the prohibited trade restraints and agreements are those which have the effect of fixing prices ${ }^{29}$ or of excluding others from a market, ${ }^{51}$ or those which are "unreasonable." 62 Prohibited monopolies are those arising from or maintained by unreasonable trade restraints. ${ }^{53}$

Unit operation is a type of horizontal combination. It is, however, combination justified by business efficiency and the nature of oil reservoirs, not by price considerations. In the usual unit agreement the original lessees take their share of the liquid production in kind, while gas may have to be marketed by the unit as a whole. ${ }^{\text {st }}$ Consequently there is no change in the number of sellers of crude oil because of unitization. However, unit operation might be attacked as changing the competitive situation by reducing competition in the gas market, by restricting crude production, or by serving as a breeding ground for

48. Worts v. Hoagland, 114 U.S. 606 (1885) (swamp development district); Fallbrook Irrigation District v. Bradley, 164 U.S. 112 (1896) (irrigation district); Head v. Amoskeag MIfg. Co., 113 U.S. 9 (1885) (overfowing upstream land); Sce German, stipra note 23 , at 125 ; Williams, stipra note 13 , at 69 .

49. 26 STAT. 209 (1590), 15 U.S.C. $\$ \$ 1-7$ (1940). Undoubtedly oil and gas production is within the ambit of the "commerce power" and the Sherman Act. See: Wichard v. Filburn, 317 U.S. 111 (1942); United States v. Southeastern Underwriters, 322 U.S. 533 (1944).

50. United States v. Socony-Vacuum Oil Co., 310 U.S. 150 (1940); United States v. Trenton Pottery Co., 273 U.S. 392 (1927).

51. See Associated Press v. United States, 326 U.S. 1 (1945), Fashion Origination Guild v. Federal Trade Commission, 312 U.S. 457 (1941).

52. Standard Oil Co. v. United States, 221 U.S. 1 (1910). The rule of reason seems still to be alive: United States v. United States Gypsum Co., 16 U.S.L. Weels 4201, 4212 (U.S. March 8, 1948).

53. United States v. Paramount Pictures, 16 U.S.L. Week 4359, 4399 (U.S. Mray $3,1948)$.

54. See, e.g., the provision of the Oklahoma statute. 52 OrLA. Stat. Amz. 286.10 (Supp. 1947). 
price conspiracies among the participating crude sellers. So long as joint gas selling and crude production restriction involve only those acts justifiable to increase recoveries and prevent waste, as opposed to acts designed to fix prices or eliminate competition, it would seem folly to apply the Sherman Act. ${ }^{55}$ This statement is fortified by the fact that under compulsory unit operation, gas sales and production restriction will be carried out under agreements approved by state officials. ${ }^{\text {ba }}$ If people wish to conspire regarding prices, it may be doubted that the presence or absence of unit operation will have much effect on their efforts.

It may be further objected that unit operation is a device whereby the "major" oil companies may enhance their dominant position in the industry. ${ }^{57}$ Favorable to domination of a unit's policies by the majors are the facts that the largest property interest holder is usually chosen as operator of the unit, and that voting strength within unit committees is proportional to property interest. To protect the small operator, it is usually provided that, regardless of property interests, the committee cannot approve a measure unless a minimum number of individuals favor it. Furthermore, any participant has recourse to the courts when he feels that he is discriminated against by a unit committee or by administrative agency action. ${ }^{58}$ Yet another factor, competition from other producing fields, would tend to prevent the majority interest in any unit from unduly restricting production to increase crude prices. ${ }^{59}$ In view of the benefits possible it seems wrong to deny unitization because it might give the "majors" a slight increase in power within the industry. If the position of the major companies is presently an unlawful one, the remedy is anti-trust prosecution addressed to their economic power in the industry as a whole, not denial of unit operation.

Of particular interest is the recent case brought by the Government against the Cotton Valley Operators Committee charging violation of Sections 1 and 2 of the Sherman Act. ${ }^{00}$ The defendant Committee has,

55. See Myers, supra note 15, at 281; Moses, supra note 16, at 764; Brown and Myers, supra note 16, at 473; King, supra note 16, at 326.

56. Parker v. Brown, 317 U.S. 341 (1942).

57. See Rostow, op. cit. supra note 3, at 10,120; Testimony before the Cole Committec, supra note 5, at 1785; Cook, Control of the Petroleum Industry By the Major Ort. Companies (TNEC Monograph 39, 1941) ; Farish and Pew, Review and Criticism on Behalf of Standard Oil. Co. (N.J.) and Sun Oll Co. of Monograpu No. 39 witu RejoINder By Monograph Author (TNEC Monograph 39-A, 1941).

58. See 52 Okza. Stat. ANv. $\$ \$ 286.5(\mathrm{a}), 286.5$ (e), 286.7 (Supp. 1947).

59. Oliver and Umpleby, supra note 12 , at 110 .

60. Civil Action No. 2209 (W.D. La. June 17, 1947). See United States v. Cotton Valley Operators Comm., 75 F. Supp. 1 (W. D. La. 1948) for a first opinion ruling on pre-trial motions. The factual description of the field given here is taken from the complaint and from Weber, Cotton Valley Agreement, 39 OIL AND GAS Journs., No. 11, D. 168 (July 25. 1940). 
since 1940, managed recycling operations in a Louisiana condensate field under a voluntary unitization agreement later made compulsory by the Conservation Commissioner. The violation charged principally involves the exclusion of others from, and the elimination of competition in, producing, recycling plant processing and transporting and selling of the hydrocarbons from the field by the device of these functions being carried out jointly by all the owners of the field. Fears that the suit represents a direct attack on unitization should be allayed by the Justice Department's announcement that the suit does not attack any activity necessary to conservation of natural resources or the prevention of waste. ${ }^{61}$ The announcement recognizes that the joint production inherent in unit operation does not violate the Sherman Act. The suit then appears to be an attack on the vertical integration involved in the joint handling of products in the stages from surface processing through sale. ${ }^{62}$ Joint handling of liquid products in the transportation and selling stages is, ordinarily, not necessary to unitization. The extent to which joint activities are "necessary" in the surface processing stage is uncertain and must be determined by court decisions. The Cotton Valley decision will be the first on this question.

That the policy of the Sherman Act hardly applies to unit operation when strictly limited to the combinations necessary for efficient production seems further attested by the federal statute ${ }^{63}$ providing for compulsory unit operation on federally owned lands.

Since the federal statute already indicates that congressional policy favors unitization, it would seem unnecessarily time-consuming to enact a law proclaiming acts necessary to waste prevention and correlative rights protection not subject to the Sherman Act. It is generally agreed, however, that a state compulsory unitization statute should contain a clause exempting the unit from anti-trust prosecution under state statutes. ${ }^{64}$

61. See Legal Committee, Report, 6 IOC Q. BuLr., No. 2, p. 71 (August 1947); 39 National Petroleum News, No. 36, p. 40 (September 3, 1947).

62. As such, the trial of the suit will be governed by the doctrine that a vertieally organized business is not illegal per se, but may run afoul of the Sherman Act if there is no legitimate business reason for its creation, or if a power to exclude others from a market exists together with a purpose or intent to do so. United States v. Paramount Pictures, 16 U.S.L. WeEK 4389, 4400 (U.S. Mfay 3, 1948).

63. 60 Stat. 952, 30 U.S.C.A. $\$ 226$ (Supp. 1946).

64. See Myers, stipra note 15, at 2S1; Legal Committee, Interstate Oil Compact Commission, 6 IOC Q. Bur. 72 (1947); Statutes of the type referred to have already been passed in a number of states; see 26 ALA. CoDE $\$ 179(36)$ E (Supp. 1945); Arkansas Laws (1939), Act. 105, $\S 15 \mathrm{C}$ in Pope, Digest of Arknassas Statcres 1010 (Supp. 1944) ; FlA. Stat. ANw. \$377.29 (Supp. 1946) ; GA. Covz Ams. §43-717e (Supp. 1945) ; MIIss. Code Ann. $\$ 6172$ (1942); N.C. Gen'l Stat. $\$ \$ 113-393 \mathrm{C}$ (Supp. 1946); 52 OrLA. Stat. ANn. $\$ 286.17$ (Supp. 1947). 


\section{Lessee's Obligations}

The rights and duties of the lessees in an oil field are defined in the lease contract and its implied covenants; the latter place on the lessee the obligation of exercising reasonable diligence in drilling an exploratory well, in further development if hydrocarbons are discovered, in operating the property for maximum recovery, and in protecting the lease against drainage. ${ }^{65}$ In the event that unit operation is adopted, a new contract is necessary since the lessee surrenders to the discretion of the unit management the power to carry out the first three implied covenants, and the fourth becomes meaningless by the agreement to accept a proportion of the unit production regardless of the lease from which it was produced.

Some concern has been expressed as to just what the lessee's rights and duties would be under unit operation. ${ }^{66}$ The courts have resolved the problem by declaring that under compulsory unit operation the lease contract and its implied covenants are reformed in law as necessary to carry out unit operation. ${ }^{67}$ This result follows from the rule that all contracts are subject to a reasonable exercise of the police power without violating the constitutional mandate against impairment of the obligation of contracts. Unit agreements must, however, preserve royalties, overriding royalties, and oil payments. ${ }^{65}$ The lessor cannot, on the other hand, cancel the lease for failure of the lessee to comply with the original implied covenants..$^{69}$

On factual grounds, even if a lessor were allowed to cancel leases subjected to unitization for noncompliance with the original covenants, the lessor would not increase his income. The rate and manner of exploitation of his land is set by the unit agreement, regardless of whom he chooses as lessee. ${ }^{70}$

65. Tidewater Associated Oil Co. v. Stott, 159 F. 2d 174, 176 (C.C.A. 5th 1946), cert. denied, 67 S.Ct. 1306 (1947), Note, 25 Tex. L. Rev. 690 (1946) ; MenriLL, CovENANTS IMPlied IN OIl and Gas Leases 73 (1940).

66. See Marshall and Myers, supra note 9, at 62, 64. On this general problem see MerRILI, op. cit. stpra note 65, at 478; Wright, Some Economic Aspects of the Community Oil Lease, AIMME, PET. DEv. AND TECr. 769 (1925); Merrill, Current Problems in the Law of Implied Covenants in Oil and Gas Leases, 23 TEx. L. REv. 137 (1945); Shank, Some Legal Problems Presented by the Pooling Provisions of the Modern Oil and Gas Leases, 23 TEx. L. REv. 150 (1945); Brown and Myers, Some Legal Aspects of Water Flooding, 24 TEx. L. REv. 456, 475 (1946).

67. Crichton v. Lee, 25 So. 2d 229 (La. 1946) ; Alston v. Southern Production Co., 21 So. 2d 383, 386 (La. 1945) ; Hardy v. Union Prod. Co., 20 So. $2 d 734$ (La. 1945); Hood v. Southern Prod. Co., 19 So. $2 d 336$ (La. 1944); Placid Oil Co. v, North Central Texas Oil Co., 19 So. 2d 616 (La. 1944); Hunter Co. v. Shell Oil Co., 31 So. 2d 10 (La. 1947); Ohio Oil Co. v. Kennady, 28 So. 2d 504 (La. App. 1946).

68. Cf. Dillon v. Holcomb, 110 F.2d 610 (C.C.A. 5th 1940).

69. See cases cited note 67 supra.

70. See cases cited note 67 supra. Especially Crichton v. Lee, at 234, and Hardy v. Union Prod. Co., at 736. 


\section{Tax Liability}

A fourth major objection raised to compulsory unit operation is that it will increase the federal tax liability of the participants because the unit will be classified as an "association" taxable as a corporation. ${ }^{71}$ The equities definitely favor not so taxing unitized properties. Under a compulsory statute those bearing the added tax liability are forced to unitize by law. Failure to tax unit projects as associations would represent no tax loss to the government, but would still permit taxes equal to those realized from individually operated leases.

Under the law, however, the tax status of unit projects is by no means certain. The fact that the unit agreement might be considered a tenancy-in-common or a mining partnership in state law is not controlling in the federal tax field. ${ }^{72}$ Instead the classification is governed by standards laid down in Morrisey $v$. Commissioner. ${ }^{73}$ There it is stated that an "association" exists when the participants are associated in an enterprise for business gain, and the enterprise exhibits some of the five salient features of a corporation: (1) title to the property in the enterprise; (2) centralized management; (3) continuity uninterrupted by deaths among the beneficial owners; (4) transfers of beneficial interests possible without affecting the continuity; and (5) limitation of the personal liability of the participants. There has been no case decided on the taxability of a unitized field under this precedent. ${ }^{74}$ One line of analogous cases holds that tenants-in-common may individually appoint a common agent to exploit their lease, without incurring "association" taxability. ${ }^{75}$ In this situation the tenants have not "associated" themselves, title to the property is in the tenants instead of the operating agent, any centralized management comes about through

71. On this general problem see Mfyers, supra note 15 at 280; Brown and Mfyers, supra note 16 at 474 ; King, supra note 16 at 329.

72. Burk-Waggoner Oil Ass'n v. Hopkins, 269 U.S. 110, 114 (1925).

73. 296 U.S. 344 (1935). Companion cases are: Swanson v. Commissioner, 296 U.S. 362 (1935) ; Helvering v. Combs, 296 U.S. 365 (1935) ; Helvering v. Coleman-Gilbert Association, 296 U.S. 369 (1935).

74. Myers, supra note 15 at 280 , reports that a suit brought to tax the East Alice, Texas, unit project as an association was subsequently settled by means of a stipulation that the unit was not taxable as an association.

75. Stantex Petroleum Co., 38 B.T.A. 269 (1938); C.A. Everts ef al. James Lease Syndicate v. Commissioner, 38 B.T.A. 1039 (1938); T.A.Johnson, Trustee, 38 B.T.A. 1199 (1938); Commissioner v. Rector \& Davidson, 111 F. $2 d$ 332 (C.C.A. 5th 1940), cert. denied, 311 U.S. 672 (1940); Commissioner v. Horseshoe Lease Syndieate, 110 F.2d 748 (C.C.A. 5th 1940), cert. denied, 311 U.S. 666 (1940); Henry Lilly Lease, 44-137 P H Memo TC (1944) ; H R Hanover, 45-287 P H Memo T.C. (1945). Bul cf. Wabash Oil and Gas Ass'n v. Commissioner, 160 F. 2d 658 (C.C.A. 1st 1947), ecrt. denicd, 331 U.S. 843 (1917); Thrash Lease Trust v. Commissioner, 99 F. $2 d 925$ (C.C.A. 9th 1938); Commissioner v. Fortney Oil Co., 125 F.2d 995 (C.C.A. 6th 1942); Keating-Snyder Trust v. Commissioner, 126 F.2d 860 (C.C.A. 5th 1942); Commissioner v. Nebo Oil Co., Trust, 126 F.2d 148 (C.C.A. 10th 1942). 
the agency appointment and not by election, no continuity of management by the appointed agent is provided for on the occasion of a tenant's death or the transfer of his interest, and there is no limitation on the personal liability of the tenants other than that liabilities incurred by the common agent are divided among the tenants in proportion to their percentage interests in the whole. Under the usual unit agreement, by way of comparison, there is a definite "association" among the participants in forming an operators' committee to direct the unit operations. It can be argued that this "associating" is not for a business purpose since waste prevention through increased recovery is the principal reason for unitizing. Title to the property remains in the participants; the managing committee is asserted to be the agent of each participating lease-holder; and personal liability of the participants is unlimited; but definite arrangements are made to guarantee continuity of management in case of death of a participant or transfer of his interest; and the meetings of the operators committee are comparable in form to the centralized management found in corporations.

A Congressional declaration of the freedom of unit projects from taxation as associations is desirable to dispense with this tenable objection. A suitable compulsory unit operation statute will always contain a clause denying additional taxability under state law. ${ }^{76}$

\section{The Small Property Owner}

Some objections to unit operation are based on the belief that it cannot be carried out in a manner fair to the small operator or royalty owner. It is feared that the small property owner will not be given his proper percentage rights in the unit; that the large companies will dominate the unit management; and that the financial arrangements will not be feasible to the small operator. ${ }^{77}$ Such objections persist largely because of lack of education regarding what has been accomplished in existing unit agreements.

As already pointed out, questions regarding basis of participation have been almost wholly settled. In most instances, the engineers will be able to make accurate estimates of oil-in-place and of recoveries. If the necessary data are not available for making such estimates, unitization can be ordered on an acreage basis with provision for changing to an oil-in-place basis after sufficient data are available. The unit agreement usually provides for extensions of the areal extent of the unitized properties if such extensions have a basis in geologic fact and are proposed by a certain percentage of the participants. Retroactive adjustments of benefits received from the unit are usually not made when the area is extended. Once admitted, a property is never excluded from

76. See 52 OkLa. Stat. ANn. \$286.14 (1945).

77. See testimony before Cole Committee, stipra note 5, at 1440, 1785, 1963 and 1494. 
participation, though production on that property may cease. Production from an overlying gas-cap may be deferred, without compensation to the gas-cap owners, until the downdip oil has been produced, if necessary. ${ }^{78}$

Again, provisions are made to prevent the domination of the unit management by the large property holders. These include voting safeguards within the managing committee, and giving all participants recourse to the courts from decisions of the unit committee or supervising administrative agency.

Nor will unit operation be forced upon an area merely because the majority property interests favor it. Before a compulsory order issues, the administrative agency must make specific findings that unitization: (1) will increase recoveries and prevent waste; (2) is economically feasible to the participants; (3) is necessary to carrying out the planned program for increasing recoveries and protecting correlative rights; (4) will protect and preserve correlative rights in the pool; and (5) is in the public interest. These findings are made after a public hearing. ${ }^{70}$

Unit operations are financed by contributions from each participant, since group financing might be construed as indicating that the unitized properties are an association for tax purposes. In view of the economies to be realized through unitization, the small operator usually finds money demands on him substantially smaller than under a system of individual lease operation. Moreover, each participant has a share of the production from which to satisfy expenses. True, unit project financing may inconvenience the small operator in the unusual case of unitization's being required in an undrilled area where a lengthy development program without production is anticipated. But, if any lessee believes such a program beyond his economic capabilities, his interest should prove more readibly salable and valuable because of the planned unitization.

\section{SUMIMARY AND CONCLUSIONS}

In summary, unit operation of oil fields, the method whereby all leases covering a given underground reservoir are operated as a single

78. Miller v. Schoene, 276 U.S. 272 (1928); see Hayden, Fenerni Regulation of the Production of OIL 33 (1929); Veazey, 103 AIMIME, Pet. Dev. and Tecr. 30 (1933).

The "gas cap" problem seems to have overwhelmed the Energy Resources Committee of the National Resources Committee. See the 1939 report of the Energy Resources Committee to the National Resources Committee entitled Energy Resourecs and National Policy at page 214. The Committee finally decided that the gas cap owner should be compensated by being given an equity based on "energy credits."

On the "gas cap" problem see Umpleby, Reservoir Energy, Its Sourec, Ourncrship, and Utilization in the Production of Petrolcum, 103 AIMIME, PET. DEv. A:D TEer. 22 (1933); Umpleby, Efficient Utilization of Rescrioir Energy, 107 AMMIE, PET. DEv. AND TECH. 168 (1934).

79. See 52 OkLA. Stat. ANn. §286.4 (Supp. 1947) and App. I, §§ 3A, 3C 
lease, is the method of operating oil fields dictated by the scientific principles of reservoir behavior. No other known method makes possible such large recoveries, such low operating costs, nor such equitable distribution of the production. The possible scarcity of petroleum, coupled with its modern strategic and economic significance, justify the use of governmental institutions to bring about a regime of unit operation. The record to date indicates that some type of compulsion will be necessary. A state enacted compulsory unitization statute whereby the minority interests are forced to accede to unitization if it is favored by the majority and approved by a board of experts is not unconstitutional, does not infringe anti-trust laws, does not make the lessees liable for failure to exploit their leases under the terms of the original lease contract, and envisages an organization which can be financed and participated in equitably. The organization created under a compulsory unit operation statute may be subject to federal taxation as an association. If unitization is to be fully enjoyed, the Internal Revenue Code should be revised to obviate this possibility.

A comprehensive compulsory unit operation statute should contain sections providing for (1) the percentage of lessees which may petition the administrative agency for a compulsory order; (2) the findings the agency must make before issuing an order; (3) a state anti-trust law exemption; (4) a method for approving increases in areal extent; (5) an exemption of the unit from additional state taxation; together with provisions regarding (6) the legal relationship, property rights and obligations created by a unitization order; and (7) provisions giving any interested party the right to full hearing before the commission on any point; with (8) proper appeal to the courts. Failing advancement of hitherto unheard objections, it would seem in both public and private interest for all oil-producing states to enact statutes of this type at once. $^{80}$

\section{APPENDIX}

- The suggested compulsory unitization statute given below is modeled after the ' Oklahoma statute, 52 Okia. Stat. Ans. 286 (Supp. 1947), and that proposed by the Legal Committee of the Interstate Oil Compact Commission, 6 The INTERstate OIL CoMpact Quarterly Bulletin 105 (Nos. 3 and 4, December, 1947). The statute is designed to fit into an existing comprehensive oil and gas conservation statute. Therefore, it does not describe the makeup or procedure of the supervising administrative agency (referred to as the Commission in the statute below) nor does it give details regarding procedure for appealing from Commission rulings. Definitions are limited to those unique to unitization.

\section{Section 1. Legislative Declaration}

The Legislature finds and determines that it is desirable and necessary, under the circumstances and for the purposes hereinafter set out, to authorize and provide for

80. See appendix I for a suggested statute. 
unitized management, operation, and further development of the oil and gas properties to which this Act is applicable to the end that a greater ultimate recovery of oil and gas may be had therefrom, waste prevented, and the correlative rights of the owners protected.

\section{Section 2. Connmission Authorization}

The Commission is authorized to order, in accordance with the provisions of this act, the unitized operation of a pool or portion of a pool for facilitating the conduct of primary recovery operations, secondary recovery operations, cycling or recycling of gas, water flooding, repressuring operations, pressure maintenance operations, or any other operation designed to prevent waste or the unnecessary loss or dissipation of, or to preserve or augment, reservoir energy in all or part of any pool or field.

\section{Section 3. Petition to Commission and Order Creating Unit}

When found by the Commission to be reasonably necessary in order to carry out any of the operations mentioned in Section 2, the Commission is authorized to order the unitized operation of a pool or portion of a pool as follows:

A. There must be filed with the Commission a petition signed by or on bahalf of the owners of at least sixty (60) per cent, in surface area, of the pool or portion of a pool to be affected by the order, alleging (1) that the unitized operation of such pool or portion is necessary in order to carry out one or more of the operations mentioned in Section 2; (2) that the conduct of such operation or operations in such pool or portion will, with reasonable probability, result in the recovery of a substantially greater quantity of oil or gas than would otherwise be recovered, and will result in the prevention of waste; (3) that the reasonably estimated additional expense of conducting such operation or operations will not exceed the value of the additional oil or gas to be recovered thereby; and (4) that the unitized operation of such pool or portion will protect and preserve the correlative rights of all ouners and royalty oziners (which term as used in this section shall include the owner of an overriding royalty interest, production payment interest, and any other interest of like nature as well as the owner of royalty reserved in an oil and gas lease) in such pool or portion of pool. The petition shall also state which of the operations mentioned in Section 2 is or are proposed to be conducted, and may, but need not, have attached thereto a proposed plan for the unitized operation of the pool or portion of pool described therein, including the unitization of all royalty interests and interests of owners therein.

B. Upon filing of such petition the Commission shall hold a public hearing thereon, after notice, in the manner specified by law, at which every person interested in the pool or portion of pool described in the petition shall be entitled to appear and be heard.

C. If the Commission, after notice and hearing, finds that the necessary allegations of the petition are true on the basis of the evidence submitted at the hearing, and that the unitization is in the public interest, the Commission shall enter an order for the unitized operation of the pool or portion of pool described in the petition, in accordance with the provisions of this section; provided, however, that if deemed necessary by the Commission the order entered by the Commission may require the unitized operation of a smaller area than described in the petition. The pool or portion of pool to which the Commission's order applies in hereinafter referred to as the unit area.

D. The order for unitized operation shall describe the unit area and shall prescribe a plan for the unitized operation thereof on such terms and conditions as the Commission shall consider reasonable and proper and just and equitable to all per- 
sons having interests in the unit area, such plan to include provisions for (1) allocation among the separately owned tracts in the unit area of all oil and gas produced and saved through unitized operations and not required in the conduct of such operations or unavoidably lost (such oil and gas being hereinafter referred to as unit production), such allocation to be made on the basis of percentage interests set forth in the plan, or to be determined by a formula set forth in the plan, provided that, wherever practical unit production shall be delivered in kind to the persons entitled thereto; (2) the payment of expenses (including overhead and supervision expenses) incurred in the conduct of the unitized operation, the owner or owners of each separately owned tract in the unit area to be chargeable with the same percentage of such expenses as the percentage of unit production allocated to such tracts; the percentage of such expenses chargeable to the owner or owners of a separately owned tract shall be made a first lien upon, and payable out of the proceeds of, all such unit production excepting a one-eighth royalty interest therein, provided, the obligation or liability of the owner or owners of the separately owned tracts for the payment of expense incurred in the conduct of the unitized operation shall at all times be several and not joint or collective; (3) an operating committee to supervise the conduct of unitized operations, each person or persons responsible for developing and operating a separately owned tract or part thereof in the absence of unitization (hereinafter referred to as lessee) to be entitled to representation on such committee with the right to vote on all matters considered by the committee in proportion to the percentage of unit expense chargeable against the separately owned tract represented by him, provided, where the voting interest of a lessee is such as to control the action taken by the committee, the vote of such lessee shall not serve to carry or defeat action by the committee unless such vote is supported by a majority of the remaining lessees; (4) the selection, removal and replacement of the person or persons to be in charge of the conduct of unitized operations of the unit area; (5) adjustment among the owners of the unit area for their respective investments in wells, tanks, pumps, machinery, materials and equipment in place at the time unitized operation is commenced and taken over in connection with the conduct of unitized operation, provided, nothing contained in this Act shall be construed to require transfer to or vesting in the unit of title to the separately owned properties; and (6) such other provisions as the Commission may deem appropriate for the prevention of waste and the protection of all interested parties.

\section{Section 4. Objection to Creation of Unit}

A. The order entered by the Commission shall specify the time when the order will become effective and the circumstances under which and the manner in which unitized operation authorized by the order may be terminated. However, the order entered by the Commission shall not become effective earlier than thirty (30) days after the date on which it is entered and if there be filed with the Commission, within thirty (30) days after the entry of the order, written objections to the order, signed by the owners of thirty (30) per cent or more, in terms of surface area, of the unit area affected by the order, the Commission shall hear such objections, after notice as required by law, as soon as reasonably possible. After such hearing the Commission shall enter a new order sustaining or vacating or modifying the original order. The filing of written objections shall suspend the effective date of the original order until a time set in the new order.

B. Any person aggrieved by any order of the Commission made pursuant to this Act may appeal therefrom to the Supreme Court of the State of under the same conditions, within the same time and in the same manner as provided by law. The Supreme Court on appeal shall have jurisdiction and authority and it shall be its duty to review the record of proceedings and transcript of evidence and 
to consider the validity of the order of the Commission appealed therefrom. On appeal the order of the Commission appealed from shall be regarded as prima facic valid, fair, reasonable and equitable, but if the order is found to be contrary to the clear weight of the evidence, in any one of such respects, the same shall be vacated and set aside and the cause referred to the Commission for further prosecdings not inconsistent with the judgment of the Court; otherwise the said order shall be affirmed.

C. In addition to any other remedy provided in this Act any interested person, firm or corporation within a unit area feeling himself aggrieved by any order of the Commission or the action of a unit thereunder, may at any time institute a suit in the District Court of the County in which the greater part of the unit area is located, as in other civil suits in equity, against the other lessees vithin the unit and in such suit have his rights and equities determined. Any person aggrieved by the judgment entered in such an action may appeal therefrom to the Supreme Court of the State of - in the time and manner as appeals are taken in other civil actions. To the extent possible under existing laws the Supreme Court shall give precedence to all such appeals in the hearing and disposition thereof.

\section{Section 5. Unit Area}

A. The unitized operation of two or more pools or portions of two or more pools, as a unit, may be ordered by the Commission if the petition therefor alleges, and the Commission finds, that a substantial part of each pool or portion of pool included in the unit area, as described in the order of unitized operation, is overlaid or underlaid by a substantial part of another pool, or portion of pool, included in such unit area, and that the unitized operation of the pools or portions of pools included in such unit area is reasonably necessary for the efficient and ceonomieal operation thereof and for the prevention of waste.

B. After an order of unitized operation becomes effective the Commission shall have continuing jurisdiction to amend or modify the order or to enlarge the unit area described in the order to include contiguous portions of the pool or pools or portion or portions thereof affected by the order, or to include a pool or portion of pool which has been discovered after the filing of the initial petition for unitized operation and a substantial part of which is overlaid or underlaid by a pool or portion of pool affected by the original order, each such order of amendment or enlargement to be entered after hearing and notice on the filing of petition therefor in the same manner, and subject to all the conditions, hereinabove set forth with respect to entry of an original order of unitized operation.

\section{Section 6. Property and Contract Rights}

A. Neither the order of the Commission for the unitized operation of the unit area described in the order, nor the conduct of operations pursuant to such order, shall be deemed to create an association or partnership or any other entity. All operations conducted pursuant to any such order shall be deemed conducted for the account of the respective owners of the unit area severally. All income and benefits derived by such owners from the conduct of such operations shall be deemed the separate and several income and benefits of such owners respectively.

B. The portion of unit production allocated to a separatcly owned tract shall be deemed, for all purposes, to have been actually produced from such tract and all operations conducted pursuant to the Commission's order shall be deemed for all purposes the conduct of operations for the production of oil and gas from each separately owned tract in the unit area in fulfillment of all the express and implied obligations of the owner or owners of such tract under the lease or leases and other contracts applicable thereto. 


\section{Section 7. Anti-Trust Exemption}

A. Unitization orders issued by the Commission may provide for the extracting and separating of liquid hydrocarbons from natural gas and for cooperative marketing of gas or any product directly or indirectly extracted or derived therefrom, when the Commission finds that it is impractical to deliver such gas or products to the several owners. Acts performed in accordance with unitization orders of the Commission shall not constitute a violation of any statute of this State relating to trusts, monopolies or contracts and combinations in restraint of trade.

\section{Section 8. Definitions}

A. Pool-an underground reservoir containing, or appearing to contain, a common accumulation of oil or gas, or both, or condensate. Each zone of a general structure which is completely separated from any other zone in the structure is covered by the term "pool" as herein used.

B. Primary Recovery-the oil, gas, or oil and gas recovered by any method that may be employed to produce them through the use of a single well bore.

C. Secondary Recovery - the oil, gas, or oil and gas recovered by any method that may be employed to produce them through the joint use of two well bores.

D. Cycling -an operation in which condensate-bearing gas is displaced from a gas zone by injection of dry gas.

E. Recycling - a continuous reinjection of produced gas.

F. Water Flooding -a secondary recovery operation in which reservoir energy is augmented by the injection of water into the reservoir.

G. Repressuring-the introduction of fluid, either gas or liquid, into a producing formation for the purpose of increasing the reservoir pressure.

H. Pressure Maintenance-a primary or secondary recovery operation so conducted as to afford some degree of control over reservoir pressure decline. 